MUZIKOLOSKI ZBORNIK - MUSICOLOGICAL ANNUAL XVI, LJUBLJANA 1980

UDK 784 Lagkhner »1602«

\title{
ZBIRKA »SOBOLES MUSICA« (NÜRNBERG 1602) DANIELA LAGKHNERJA
}

\section{Jože Sive c (Ljubljana)}

Zbirka latinskih zborov »Soboles musica, id est Cantiones sacrae, quatuor, quinque, sex, septem et octo vocibus, festis anni solmnioribus pie accomodatae« skladatelja Daniela Lagkhnerja (Lacknerja), ki se je rodil nekje $\mathrm{v}$ drugi polovici 16. stoletja $\mathrm{v}$ Mariboru, je bila natisnjena 1602 pri Abrahamu Wagenmannu $\mathrm{v}$ Nürnbergu, kjer so kmalu nato izšle tudi vse druge zbirke istega avitorja. Danes hranita po en njen primerek Centralna škofijska knjižnica (Bischöfliche Zentralbibliothek) v Regensburgu in Mestni arhiv (Stadtarchiv) v Kamenzu. Dve kompoziciji iz nje (št. I in II) sta objavljeni v prvi in tretji knjigi znane zbirke »Promptuarium musicum«, ki vsebuje med drugim tudi nekaj Lukačićevih motetov in jo je leta 1622 oziroma 1627 izdal v Strassburgu Johannes Donfrid. Kot je bilo v zgodnjem baroku že v navadi, je bil dodan part continua, $\mathrm{ki}$ pa je $\mathrm{v}$ bistvu basso seguente in $\mathrm{z}$ izjemo nekaj prehajalnih tonov in izpolnitve občasnih pavz enostavno podvaja vokalni bas. Nekatere druge kompozicije zbirke »Soboles musica « so prišle $\mathrm{v}$ rokopisne zvezke, ki jih hranijo Univerzitetna knjižnica $\mathrm{v}$ Tübingenu, Proskejeva zbirka $\mathrm{v}$ Regensburgu in Državna biblioteka v zahodnem Berlinu. ${ }^{1}$

$\mathrm{Na}$ naslovni strani in ob koncu predgovora se Lagkhner imenuje »civis et organices Lostorpianus« tj. meščan in organist $v$ Loosdorfu na Nižjem Avstrijskem. Tu je svoje delo na večer pred praznikom apostola Jakoba leta 1602 tudi datiral. Že takoj iz začetka predgovora pa zvemo, da je zbirka posvečena njegovemu milostnemu gospodu in

1 Repértoire International des Sources Musicales, Einzeldrucke vor 1800, V, Kassel 1975, 200; Eitner R., Biographisches-bibliographisches Quellen-Lexikon, Graz 1959-1960, VI, 14-15; Die Musik in Geschichte und Gegenwart (MGG), VIII, 71-72; Cvetko D., Musikgeschichte der Südslawen, Kassel-Maribor 1975, 102; Flotzinger R.-Gruber G., Musikgeschichte Österreichs I, Graz-Wien-KöIn 1977, 301; Suppan W., Steirisches Musiklexikon, Graz 1962-1966, 320-321; Moser H. J., Die Musik im frühevangelischen Ósterreich, Kassel 1954, 47. 
mecenu baronu Juriju Krištofu von Losensteinu. Pri njem je skladatelj tudi služboval kot glasbenik, saj nosi $\mathrm{v}$ naslovih svojih poznejših zbirk »Flores Jessaei« (1606) in »Florum Jessaeorum« (1607) povsem nedvoumno oznako kot njegov »Symphonista « oziroma »Musurgus«. ${ }^{2}$ $\mathrm{V}$ omenjenem predgovoru najdemo še važen podatek, ki pove, da mu je dotlej dober del življenja potekal $\mathrm{v}$ senci losensteinskih perotnic (»Pars bona vitae sub umbra alarum Losensteiniarum ... mihi decursa est«.), kar jasno kaže, da je prišel $\mathrm{v}$ Loosdorf že precej pred letom 1602. $\mathrm{V}$ naslovu $\mathrm{k}$ verzom, posvečenim avtorju, označuje pesnik $\mathrm{M}$. Joann. Nigrinus Lagkhnerja kot »Musici instrumentalis et vocalis insignis« tj. kot glasbenika, odlikujočega se $\mathrm{v}$ instrumentalni in vokalni glasbi. Iz takšne stilizacije lahko glede na tedanjo prakso sklepamo, da Lagkhner ni le izvajal, ampak tudi ustvarjal instrumentalno glasibo, kar konkretno potrjuje en glas galliarde iz Centralne škofijske knjižnice v Regensburgu, ki pa po vsej priliki ni edina njegova instrumentalna skladba.

»Soboles musica« vsebuje 28 latinskih kompozicij za štiri do osemglasni zbor, ki so znatno obsežnejše kot tiste $\mathrm{v}$ obeh nekoliko mlajših zbirkah. Iz naslova razberemo, da so primerne za svečana praznična bogoslužja. Ne glede na to sta $v$ zbirki dva posvetna zbora. Kompozicija št. XVI je pesem za poroko dunajskega zdravnika in skladateljevega mecena dr. Bierdümphla, št. XXIV pa uglasbitev posvetila baronu Losensteinu, ki ga je spesnil F. Melchior Chunius in ga že beremo neposredno za predgovorom. Vse druge skladbe so, enako kot $\mathrm{v}$ mlajših zbirkah in ustrezno naslovu, liturgičnega značaja in se naslanjajo $\mathrm{z}$ redkimi izjemami na Biblijo stare in nove zaveze. Tako so besedila vzeta iz Psalmov, Evangelijev po Luku, Mateju in Janezu, Apostolskih dejanj, Knjige razodetij in Visoke pesmi. Le besedili kompozicij št. IV in XIX izhajata iz himnusa sv. Bernarda oziroma Venantiusa Fortunatusa, tekst kompozicije št. XXI pa je antifona za magnificat sv. Rešnjega telesa. ${ }^{3}$

Podobno kot Lagkhnerjevi kasnejši zbirki je tudi "Soboles musica« komponirana za različne vokalne zasedbe, le da ne vsebuje skladb, namenjenih samo visokim glasovom. Tako zahteva $\mathrm{v}$ celoti za izvajanje mešani zbor ali kombiniranje deških in moških glasov. Navadno zajemajo kompozicije približno dve in pol oktavi, $\mathrm{v}$ nekaterih primerih, predvsem ko hoče skladatelj doseči polnejšo in močnejšo zvočnost, pa je obseg raztegnjen čez tri oktave. Glasovi se gibljejo v

2 Sivec J., Zbirka »Florum Jessaeorum« (Nürnberg 1607) Daniela Lagkhnerja, Muzikološki zbornik XII, Ljubljana 1976, 6; Sivec J., Zbirka »Flores Jessaei« Daniela Lagkhnerja (Lacknerja), Muzikološki zbornik XIV, Ljubljana 1978, 19.

3 Hesbert R. J., Corpus Antiphonalium Officii, vol. III, Invitatoria et Antiphonae, Roma 1968; vol. IV, Responsoria, Versus, Hymni et Varia, Roma 1970; Repertorium biblicum totius sacrae scripturae concordantiae, I, II, Turin 1887; Manuale Sodalitatis Immacultatae Conceptionis, Vienna 1643. 
okviru posameznih skladb največkrat $\mathrm{v}$ razponu none ali decime, tenor in bas neredko tudi undecime ali duodecime; večji glasovni razpon se skoraj ne pojavi. Običajno je vsak glas aktivno vključen $v$ imitativne in akordske odseke. Štiriglasne kompozicije (št. I-V) ne zajemajo basovskega registra, ampak se zadržujejo $\mathrm{s}$ spodnjim glasiom $\mathrm{v}$ tenorski legi. Tonska globina je odsotna še tudi v več petglasnih (št. VII, X, XI, XII in XVI), kjer bas ne gre navzdol prek C, H ali B. Sicer označuje petglasje že izrazit basovski register, pri tem pa lega zgornjih glasov precej variira. Seveda basovski register nikoli ne manjka v šest-, sedem- in osemglasnih kompozicijah.

Nekoliko drugačno podobo kot zbirki »Flores Jessaei« in »Florum Jessaeorum « kaže »Soboles musica« tudi v izboru tonalitet. Če je tam miksolidijski način po pogostosti šele na tretjem mestu, tu močno izstopa (št. VII, VIII, X, XI, XII, XVI, XX, XXII, XXIII, XXV). To se zdi na prvi pogled nenavadno, saj miksolidijska tonaliteta $v$ tistem času nikakor ni bila dominantna, čeprav so jo še precej rabili. Tako je npr. pri Byrdu na tretjem, J. Gallusu na četrtem ali G. de Wertu celo na petem mestu in manj aktualna kot frigijska. ${ }^{4}$ Vendar je bil izbor modusa tudi neposredno povezan $\mathrm{z}$ vprašanjem izraznosti teksta in kompozicij. ${ }^{5}$ Miksolidijskemu načinu so renesančni teoretiki pripisovali vedro in svetlo izraznost. Pregled besedil kompozicij, ki mu v obravnavani zbirki pripadajo, pa pokaže, da so skoraj vselej izrazito radostnega značaja in večkrat zanosne božje hvalnice. Tako se zdi mogoče, da je prav takšno vsebinsko ozadje navajalo Lagkhnerja $\mathrm{k}$ uporabi tega tonskega načina. Kakor pri drugih tedanjih skladateljih miksolidijski modus ne nastopa $\mathrm{v}$ svoji čisti obliki, ampak ima ponekod zvišano sedmo stopnjo in zato je njegovo specifično svojstvo že oslabljeno. Kolikor gre $\mathrm{v}$ posameznih sicer še relativno redkih pasusih za konsekventno takšno zvišanje, lahko tudi govorimo o njegovi spojitvi z durom. V glavnem enako izrazno območje so pripisovali jonskemu modusu, ki ga predstavljajo kompozicije št. II, XVIII, XIX, XXVII in XXVIII $\mathrm{v}$ transponirani in le št. XIV $\mathrm{v}$ originalni obliki. Kot kompozicije prejšnje skupine se te naslanjajo na besedila, pri katerih je večinoma očitno veselo razpoloženje. S sedmimi primeri je zastopan tudi dorski način, ki ga najdemo $\mathrm{v}$ kompozicijah št. III, IV, $\mathrm{V}$, VI in XIII $\mathrm{v}$ originalni in št. IX in XV $\mathrm{v}$ transponirani obliki. Podobno kot miksolidijski je ta modificiran, in sicer z znižanjem šeste in zvišanjem sedme stopnje, kar ga, kolikor je to dosledno izvedeno, izenačuje z d-oziroma g-molom. Najmanjša je skupina eolskih kompopozicij: od teh zaključujeta št. XVII in XXVI na toniki, št. I in XXI pa na dominanti, tj. frigijsko, kar nam zbuja vtis $v$ zraku visečega konca.

4 Andrews H. K., The Technique of Byrd's Vocal Polyphony, London 1966, 19; Cvetko D., Jacobus Gallus Carniolus, Ljubljana 1965, 131; Mac Clintock C., Giaches de Wert, Life and Works, Bloomington 1966, 207-211.

5 Hermelink S., Dispositiones modorum: Die Tonarten in der Musik Palestrinas und seiner Zeitgenossen, Tutzing 1960, I, 17 ss. 
Poleg glavnega tonskega načina pa zasledimo $\mathrm{v}$ posameznih kompozicijah še daljšo ali krajšo prisotnost ene, dveh ali celo več drugih tonalitet. Pojav je pogostejši in izrazitejši kot $\mathrm{v}$ nekoliko mlajših zbirkah in ga je verjetno narekovala znatno širša zasnova, saj bi lahko učinkovale daljše skladbe brez spreminjanja osnovne tonalitete preveč enolično.

Učinkovit kontrast med posameznimi odstavki je dosežen $\mathrm{z}$ menjanjem tonalitete $\mathrm{v}$ drugem delu kompozicije št. XXII, ki je $\mathrm{v}$ tridobni menzuri in zasnovan, če izvzamemo kratek dodatni plagalni sklep, dosledno homofono in homoritmično. Tu je vsak stavek, ki se veže na ponavljajoče se besedilo »et spirito spontaneo confirma me« tako rekoč postavljen na svojo tonalitetno raven in na koncu tudi avtentično kadencira na svoji toniki. Tako si neposredno drug za drugim slede jonski, lidijski, jonski in miksolidijski način. V stavku, čigar tonski način lahko označujemo kot lidijski, je razen na enem mestu znižan, to pa seveda govori za močno zbližanje s transponiranim jonskim načinom. Bržkone $z$ namenom, da $s$ harmonskimi sredstvi poudari efekt teksta oziroma izraz roteče prošnje, je avtor $v$ isti skladbi uporabil za verz $\gg N e$ proiicias me a facie tua et spiritum tuum ne anferas a me miksolidijske $v$ dorsko tonaliteto in odtod še $v$ njeno dominanto, $t j$. eolsko toniko s picardijsko terco. $Z$ njo, torej velikim trizvokom na $A$, se začenja tudi zadnji del kompozicije, kjer nekoliko preseneti naše uho njegova zveza $\mathrm{z}$ osnovnim akordom G-dura, ki predstavlja toniko izhodiščnega miksolidijskega načina..

Nasprotje med svečanimi in umirjenimi uvodnimi takti kompozicije št. XIV, ki temelje na svetlih akordih tonike in dominante jonskega modusa in plesno razgibanim in strogo homofonim nadaljevanjem, izvrstno podčrtuje tudi harmonija, ki se poslužuje $\mathrm{v}$ krajšem
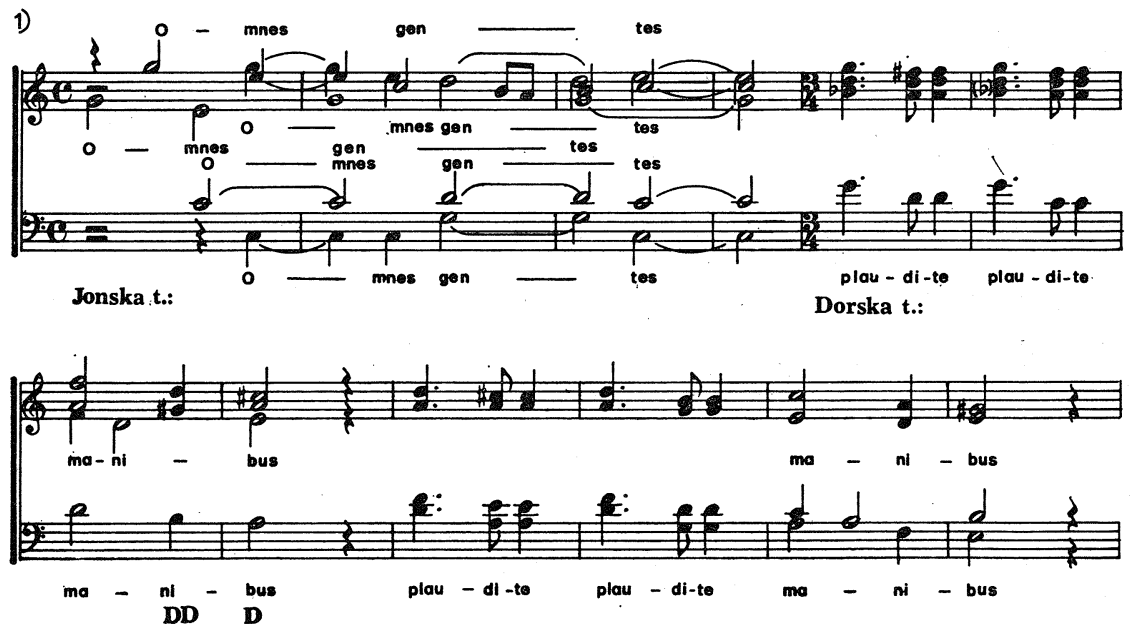
akordskem zaporedju že kar vseh v modalnem stavku običajnih àlteracij. Tu občutimo prva dva stavka $v$ tridobni menzuri na povsem drugi tonalitetni ravni in bi ju glede na akordsko strukturo lahko prej opredeljevali $\mathrm{v}$ smislu dorskega kot izhodiščnega jonskega modusa, tako da kadencira prvi na dominanti s predhodno dvojno dominanto, drugi pa izrazito frigijsko (Pr. 1). Kot $v$ prejšnji kompoziciji pa najdemo tudi $\mathrm{v}$ tej uvedbo kromatike in spremembo modusa, ki ju je mogoče pripisovati vsebinskemu momentu teksta. $\mathrm{V}$ zvezi $\mathrm{z}$ besedo »terribilis« se namreč pojavi v altu in quinti obsežen melizem - melodični postop tožečega značaja $\mathrm{v}$ okviru eolskega diapenta in diatesarona, ki vsebuje zvišan $\mathrm{g}$ in preide $\mathrm{v}$ avtentično kadenco na eolski toniki (Pr. 2).

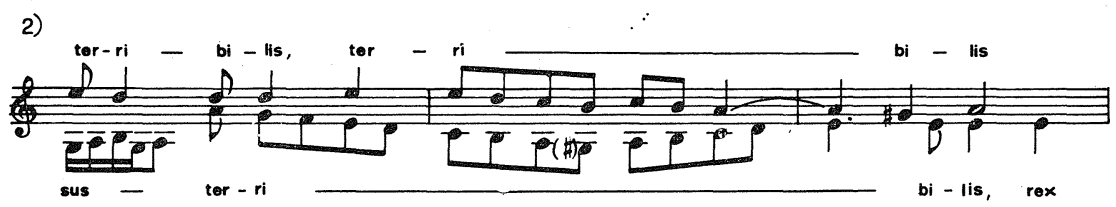

Harmonski stavek obravnavane zbirke temelji na splošno še dokaj močno na modalni osnovi in diatoniki. To pa glede na čas njenega nastanka okrog 1600 ne preseneča. Tonalno občutje dura in mola se je sicer začelo manifestirati že zgodaj v 16. stoletju in poslej je vse bolj rastel pomen jonskega in eolskega modusa, ki ustrezata po naravi duru in molu, vendar je bil za popolno zmago tonalnosti potreben zelo dolg in naporen razvojni proces. Še obdobje zgodnjega baroka je navzlic široki uporabi kromatike in continua, ki zahteva akordsko fundiranost na basu, $\mathrm{v}$ bistvu modalno. Tonalnost je dokončno zmagala $\mathrm{v}$ srednjem baroku in njeni poslednji ostanki so izginili šele proti koncu 17. stoletja. V skladu s splošnimi značilnostmi renesančnega in zgodnjebaročnega obdobja, so se manifestirale tendence za uveljavljanjem novega tonalnega občutja predvsem znotraj teoretično utemeljenega in priznanega sistema modalnosti. Vse močnejše so postajale konec 16 . in na začetku 17. stoletja $\mathrm{v}$ madrigalu, a so bile občasno precej aktualne pri nekaterih vodilnih mojstrih sakralne glasbe. Čeprav ne tako razločno, so se odrazile tudi v Lagkhnerjevem opusu. Primerjava njegovih zbirk pa pokaže, da so zaznavnejše $\mathrm{v}$ bolj reprezentativni »Soboles musica« kot v skromnejše zasnovanih »Flores Jessaei « in »Florum Jessaeorum«. Tako najdemo $\mathrm{v}$ prvi nekoliko pogosteje odseke $\mathrm{v}$ duru ali molu ali uporabo kromatike na način, ki povzroči večjo ali manjšo oddaljitev od modalne osnove. Vzporedno se pojavlja še moduliranje $\mathrm{v}$ bolj ali manj novejšem harmonskem smislu. Nasploh je kromatika nekoliko $\mathrm{v}$ porastu, čeravno gre $\mathrm{z}$ eno samo izjemo le za alteracije, običajne $\mathrm{v}$ modalnem stavku.

Izjema je kompozicija št. I, kjer se pojavi v cantusu sklepnega dela (»Alleluia«) ton dis. Ta ima izrazito harmonski značaj in je terca 
$\mathrm{v}$ H-durovem akordu, ki ima $\mathrm{v}$ danem kontekstu funkcijo dominante $\mathrm{k}$ sledečemu e-molovemu akordu. Hkrati je omenjeni del tudi primer začasnega iztrganja iz okvira modalnosti. V njem se namreč vrste kratki pasusi, ki so, če gledamo z današnjega vidika, v G-duru, e-molu, $\mathrm{C}$-duru in a-molu ter neposredno modulirajo drug v drugega. Skladba bi se pravzaprav lahko končala že kar na toniki eolskega načina, ki je njen temeljni, vendar služi ta hkrati kot subdominanta $\mathrm{k}$ sklepne$\mathrm{mu}$ akordu na frigijski toniki (Pr. 3).

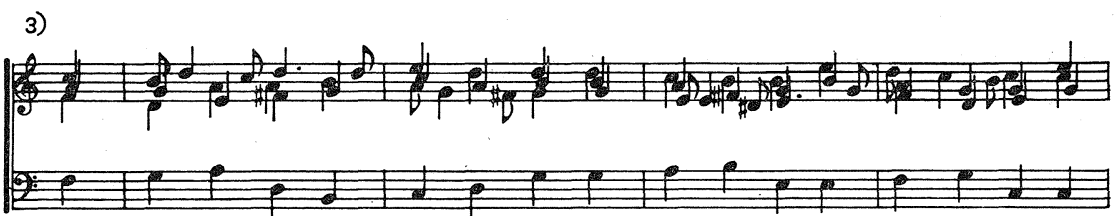

(G)

(e)

(C)

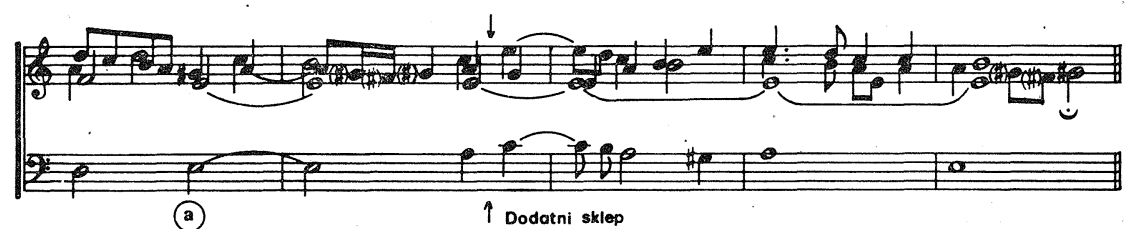

Znatno uveljavljanje tonalnega občutja in zbližanje z G- in C-durom, kar je zvezano še $z$ ustreznim moduliranjem iz enega $v$ drugega, opažamo npr. $\mathrm{v}$ kompoziciji št. XX. Tu občutimo pasus »Quid statis intuentes in coelum? « predvsem kot C-dur, ki na koncu preide $\mathrm{v}$ G-dur in se tako vrne $\mathrm{v}$ toniko izhodiščnega miksolidijskega načina. Vtis G-dura zbuja zaradi pogosto zvišane sedme stopnje tudi neposredno nadaljevanje, ki pa kadencira $\mathrm{z}$ odklonom $\mathrm{v}$ subdominanto tj. $\mathrm{v} \mathrm{C}$-dur. $\mathrm{V}$ refrenu »Alleluia«, kjer je dosežena harmonska barvitost z običajnimi alteracijami, si slede za naše občutje tonalitete C-, A-dur, a-mol, F- in D-dur. Pri tem gre za vključitev nekaj trizvokov z zvišano terco (Pr. 4). Sledi pasus, ki se praktično izkaže spet kot C-dur z moduliranjem $\mathrm{v}$ dominanto $\mathrm{v}$ kadenci. Medtem ko pozneje dlje časa opažamo omahovanje med miksolidijiskim načinom in G-durom, le-ta v sklepu povsem prodre.

4) (c)

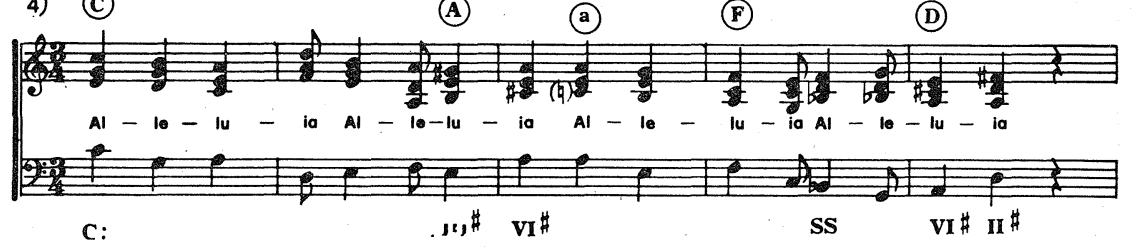


Prisotnost F-dura je precej evidentna npr. V kompozicijah št. XXVII in XXVIII. Prva je harmonsko zelo preprosta, zvočnost druge pa je, vsaj za naše pojmovanje, kar svojstveno obarvana. Št. XXVIII poteka sprva kot F-dur. Potem ko kadencira na tonični paraleli, nekoliko preseneti odmik v G-dur. V odstavku »Deo patri et Filio, sancto simul paracleto«, ki je dodeljen I. zboru, pa nastopi vrsta alteriranih akordov: A-, D-dur, c-mol, D-Dur in g-mol, ki nakazujejo $\mathrm{v}$ obrisu g-mol in bi jih $\mathrm{v}$ tem okviru lahko interpretirali $\mathrm{v}$ smislu funkcij $\mathrm{T}$, $\mathrm{DD}, \mathrm{D}, \mathrm{S}, \mathrm{H}_{6}^{5}, \mathrm{D}$ in $\mathrm{T}$ (Pr. 5). Kar pestro raznolikost tonalitet izkazuje obsežnejši odsek $\mathrm{v}$ tridelni menzuri, sestavljen iz več kratkih stavkov v F-duru, d-molu, D-duru, G-, C- in ponovno F-duru.

5)

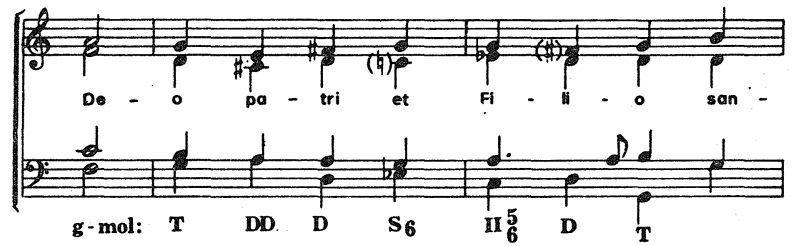

Podobno kot za Lagkhnerjevi mlajši zbirki je tudi za »Soboles musica « značilno kadenciranje, ki je neredko izrazito akordsko oziroma harmonske narave in zajema po tri ali več glasov hkrati. Ker pa so tu skladbe dosti obsežnejše, je njegova vloga kot oblikovnega dejavnika $\mathrm{v}$ smislu preglednega vertikalnega členjenja celote $\mathrm{v}$ posamezne dele in odstavke še toliko bolj pomembna. Sam način kadenciranja in njegova namestitev sta neposredno povezana $z$ vprašanjem uporabe tonalitet in harmonsko strukturo kompozicijskega stavka. Tvorba kadenc na specifičnih stopnjah je odločilen moment pri določanju modusov tako $\mathrm{v}$ enoglasju kot polifoniji. Zato je povsem upravičena Jeppesenova trditev, da se manifestira individualen značaj vsakega modusa prav $\mathrm{v}$ tem, katerim kadencam daje prednost in katerih se izogiba. $^{6}$

Glede nameščanja kadenc $\mathrm{v}$ zvezi $\mathrm{s}$ posameznimi modusi se pokaže pri Laghknerju $\mathrm{v}$ glavnem enaka slika kot npr. pri Palestrini ali Byrdu. ${ }^{7}$ Tako nastopajo $\mathrm{v}$ miksolidijski tonaliteti kadence največ na I., V. in IV. in veliko manj na II. in VII. stopnji, kadenciranja na VI. stopnji, ki se enako kot na II. pojavlja v tedanji praksi le redko, pa sploh ne najdemo. Pri kadenciranju na II. stopnji ima zadnji trizvok navadno zvišano terco. $V$ jonskem modusu so najbolj številne kadence na I., V. in VI., a dosti manj na II. stopnji. Od teh zaključujeta kadenci na VI. in II. stopnji večkrat $\mathrm{z}$ durovim trizvokom. Kaden-

7 Andrews H. K., ib., 17; Jeppesen K., ib., 62-63.

${ }_{6}^{6}$ Jeppesen K., Kontrapunkt, Leipzig 1956, 62. 
ci na IV. in III. stopnji, ki veljata na splošno za izjemni, odkrijemo le dvakrat oziroma enkrat. Dorske kompozicije kadencirajo največkrat na I., V. in III. stopnji; kadenci na IV. in VII. stopnji sta tu znatno manj običajni, medtem ko srečamo na sploh izjemno kadenco na II. stopnji $\mathrm{v}$ enem samem primeru. $\mathrm{V}$ eolskem tonskem načinu je močno v ospredju kądenciranje na I. in III. stopnji, na VII. in IV. stopnji pa je znatno manj v rabi. Redkost kadenciranja na IV. stopnji vsekakor preseneča, ker je bilo sicer $\mathrm{v}$ omenjenem modusu zelo priljubljeno. Po enkrat se pojavita tudi kadenci na VI. in V. stopnji; slednja je veljala za redkost.

Najbolj preprosto je kadenciranje $\mathrm{v}$ kompozicijah št. II in XVIII in ostaja, z eno samo izjemo na VI. stopnji, kar na toniki. Zelo preprosto kadenciranje močno prevladuje tudi $\mathrm{v}$ kompozicijah št. VII, XIX in XXVII, kjer srečamo razen na toniki le še po dvoje kadenc na dominanti. Sicer vsebujejo skladbe zbirke »Soboles musica« po tri ali štiri vrste kadenc, kompozicija št. XIV pa je $v$ tem pogledu posebno pestra in izkazuje vse, ki so $\mathrm{v}$ jonski tonaliteti možne. Kadence $\mathrm{v}$ notranjosti so skoraj vselej avtentične in so torej uvedene $\mathrm{z}$ ustrezno dominanto, ki neredko zahteva kromatsko spremembo. Zato jih navadno občutimo kot modulacijski odklon, v vrsti primerov že kar v novejšem harmonskem smislu. Več kot polovica kompozicij ima na koncu dodan poudarjen plagalni sklep.

Dasiravno je struktura zbirke »Soboles musica « na splošno dokaj polifona, se pokaže nasproti zbirkama iz leta 1606 in 1607 le občutna razlika, ki je $\mathrm{v}$ tem, da je $\mathrm{v}$ vrsti. njenih skladb dosti izrazita homofonija, ki se ne omejuje na kratke akordske bloke in pasuse $\mathrm{v}$ tridelni menzuri. Vloga enega in drugega načina gradnje je $v$ renesančni glasbi enake važnosti in njuna prisotnost je $\mathrm{v}$ daljših kompozicijah, kakršne vsebuje »Soboles musica«, zavoljo efektne kontrastnosti bolj ali manj nujna. Tako je konsekventno polifono oblikovan stavek $\mathrm{v}$ tej zbirki izjema, povsem homofone skladbe pa se tu sploh ne pojavljajo. Akordi nastajajo predvsem kot rezultat vodenja več istočasno potekajočih melodičnih linij oziroma pravilnih intervalskih razmerij med njimi in imajo vlogo sozvočne tvorbe brez izrazitejše funkcionalne narave. Takšna, kot jo imenuje M. Bukofzer, intervalska harmonija, ${ }^{8}$ je še sploh dominanten fenomen renesanse. Vendar se začenja ob njem že vse bolj uveljavljati pojmovanje akorda $\mathrm{v}$ funkcionalnem smislu in koncipiranje partov kot zvočno enovitega kompleksa. Da je to pojmovanje našlo dovolj razločen odmev tudi pri Lagkhnerju, je med drugim razvidno iz navedenih primerov, kjer je trizvok že oblikovan $\mathrm{s}$ tendenco dura in mola.

Ko razpravljamo o strukturi zbirke »Soboles musica «, se zdi umestno ločiti štiri- in petglasne skladbe od tistih $z$ večjim številom partov, ker obstajajo $\mathrm{v}$ tem pogledu med njimi določene razlike. Štiriglasje

${ }^{8}$ Bukofzer M., Music in the Baroque Era, New York 1947, 10-12. 
karakterizira močna prevlada polifono imitacijskega načina. Izjema je kompozicija št. I z dosledno homofono grajenim srednjim in zaključnim odsekom, ki privlačita predvsem s svojo mehko in nasičeno zvočnostjo. Kot pa kažejo kompozicije št. VI, VII, XIII, XIV in XVI, je linearno načelo prominentno tudi $v$ petglasju. Vendar je tu že nekaj skladb (XI, XII, XV), kjer ima imitacija manj važno vlogo in je težišč na homofoniji, ki pa ni stroga, ampak prej psevdopolifonija. Akordska kompaktnost je zrahljana z ritmično diferenciacijo glasov, njihovim zaporednim vstopanjem ter uvajanjem prehajalnih oziroma menjalnih tonov. Kljub temu ni mogoče govoriti o pravem razvoju in medsebojnem prepletanju samostojnih melodičnih linij. Nekje na sredi med prvimi in drugimi so kompozicije št. VIII, IX in X, pri katerih opažamo $\mathrm{v}$ glavnem ravnovesje med obema $\mathrm{v}$ osnovi nasprotnima načinoma gradnje. $V$ stavku s šestimi ali več glasovi je polifonija večinoma manj izrazita kot $v$ štiri- in petglasju. Tako sta kompoziciji št. XVII in XXVI močno homofoni in o imitaciji lahko govorimo na nekaj mestih le toliko, kolikor druga glasovna skupina povzame odstavek prejšnje. Homofonija, precej vezana na homoritmiko in zvočno kompaktnost, a ponekod razrahljana in po glasovih ritmično in melodično poživljena, odločno dominira tudi v kompoziciji št. XXIV, kjer se pojavi imitacija le enkrat mimogrede. Sicer pa, če izvzamemo imitacijski sklep, kaže najbolj homofono podobo kompozicija št. XXVIII, ki se odvija kot zaporedje masivnih akordskih blokov. Homofonija oziroma psevdopolifonija je $\mathrm{v}$ ospredju še $\mathrm{v}$ kompozicijah XIX, XX, XXI in XXII, kjer pa linearnost nikakor ni prezrta in nastopa imitacija $v$ nekaj ali več odsekih. Medtem ko sta $v$ št. XVIII polifona in homofona komponenta približno enako pomembni, pa je seveda $\mathrm{v}$ nekaterih skladbah $\mathrm{z}$ večjim številom glasov (št. XXIII, XXV, XVII) spet težišče na polifoniji.

Da $v$ »Soboles musica« imitacija ne manjka navzlic občasni prominentnosti homofonega principa niti $\mathrm{v}$ enem samem primeru in se več kot dve tretjini skladb že imitacijsko začenja, ne preseneča, če vemo, da je imitacija skozi vso renesanso že od konca 15. stoletja naprej standardna tehnika, ki služi za trdnost in enovitost tonske zgradbe. V primerjavi s poznejšima zbirkama pa je tu neredko imitacijska izvedba umetnejša, kar je tudi pripisovati nasploh zahtevnejšemu in širšemu konceptu večine kompozicij. Tako je ponekod značilno istočasno uvajanje dveh različnih tem in teme $\mathrm{v}$ dveh variantah oziroma teme in njene inverzije. Kot v zbirki »Flores Jessaei« se včasih druži z imitacijo tudi sekvenčno ponavljanje in spreminjanje teme, kar prispeva $\mathrm{k}$ organski rasti dela kompozicije.

Lep primer pojavljanja dveh tem hkrati in preobražanja teme je uvodni del kompozicije št. VI. Tu se pojavlja prva tema, ki se veže na besedi »Veni Domine « in postopoma pada v okviru tetrakorda, vseskozi nespremenjena. Nasprotno je druga na besedi »et noli« pravzaprav le ritmično konstantno, a melodično variabilno miselno jedro, 
čigar prisotnost $\mathrm{v}$ posameznih glasovih pa je vseskozi jasno zaznavna (Pr. 6).

Dve varianti iste teme najdemo npr. $\mathrm{v}$ umirjenem in zadržanem uvodnem pasusu kompozicije št. III. Prvo prineseta cantus in $\mathrm{v}$ spodnji oktavi bas, drugo, ki se razlikuje od prejšnje po tem, da ima intervalski postop razširjen od sekunde na terco, pa $\mathrm{v}$ unisonu cantus 2 in 3. Spremembo je tu narekoval harmonski razlog, ker sicer $\mathrm{v}$ danem zaporednem vstopanju glasov $v$ 4. taktu ne bi bila mogoča konsonančna akordska tvorba (Pr. 7).

Kar o treh variantah iste teme pa je mogoče govoriti pri imitacijskem začetku kompozicije št. IX, ki ga označujeta spevnost in ekspresivnost preprosto in skladno vodenih melodičnih linij (Pr. 8). Tudi tu gre za modifikacijo iz harmonskega razloga. Ko vstopi tenor kot četrti

6)

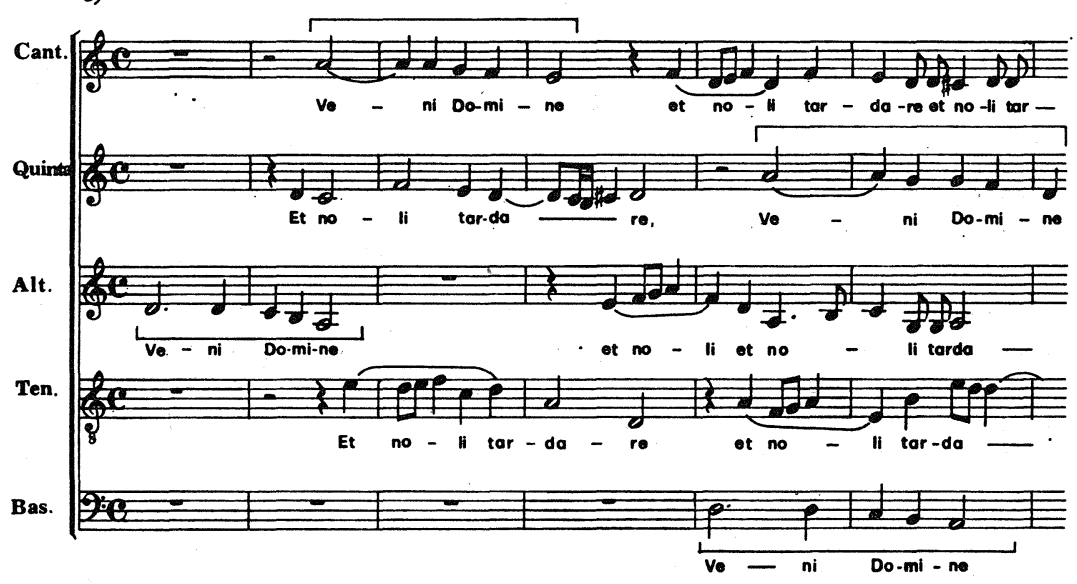

7)

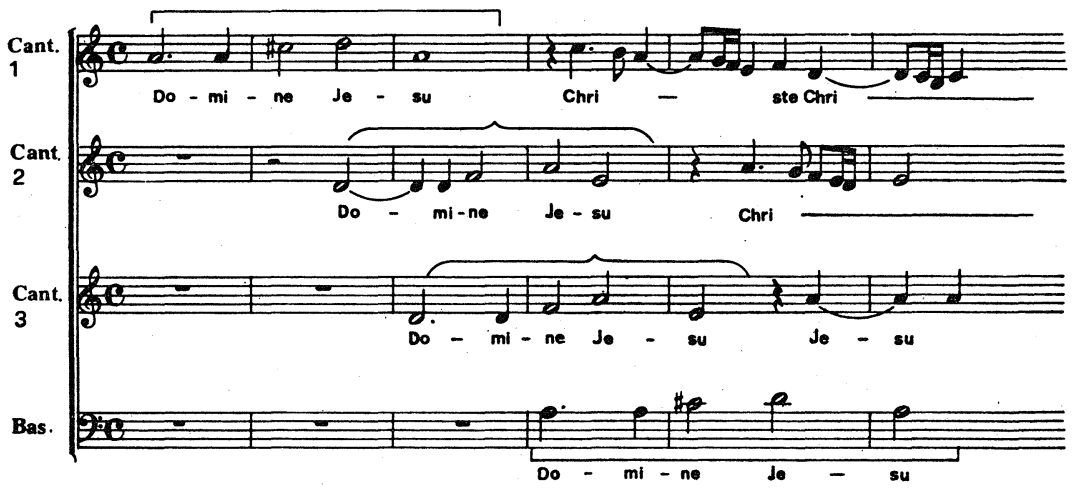


8)
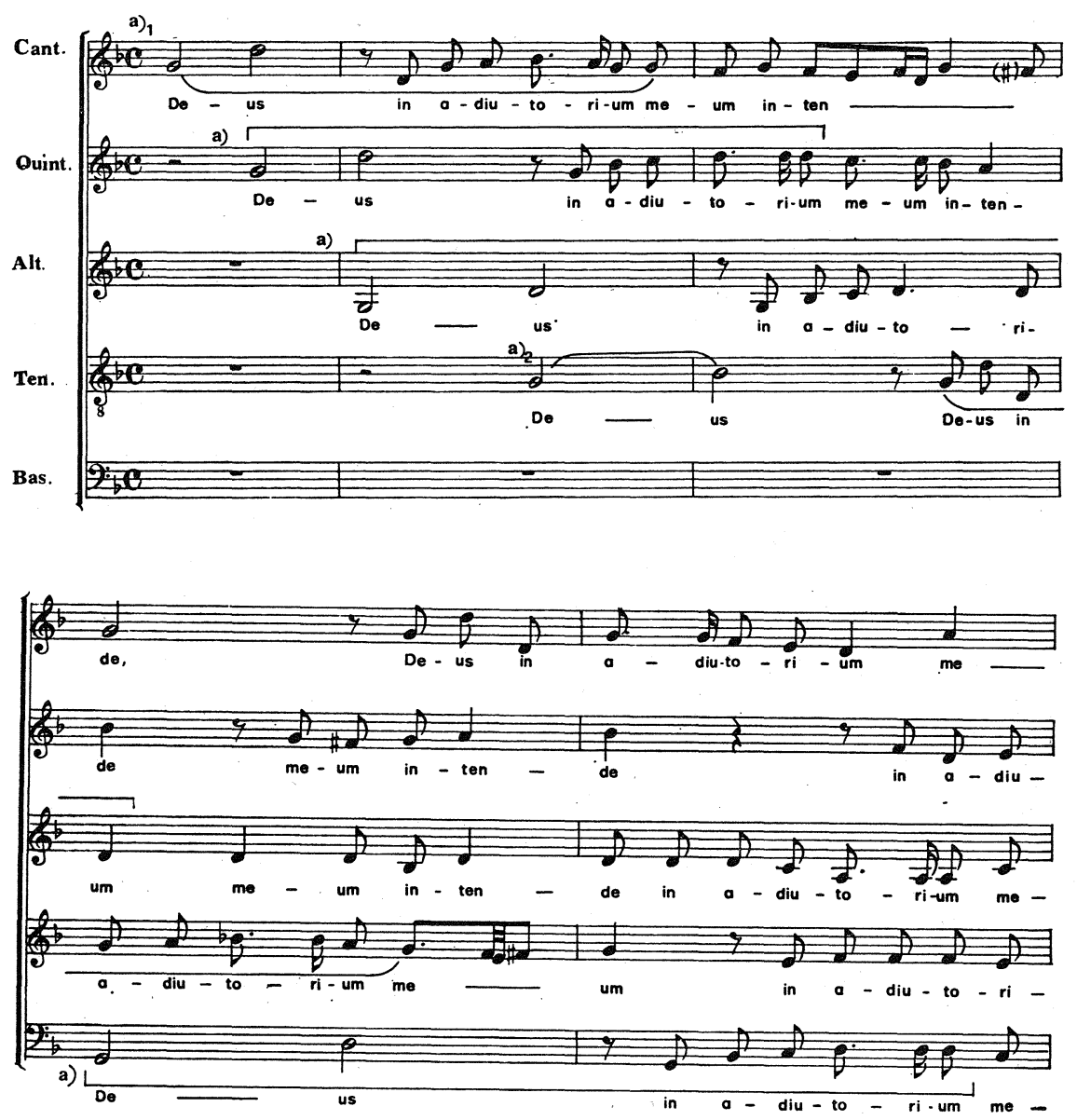

zaporedni glas, je $\mathrm{v}$ temi prvi intervalski postop krepke kvinte navzgor zmanjšan na mehko malo terco, kar omogoči polni trizvok oziroma sekstakord na prvo dobo tretjega takta. Prvotni intervalski postop se pojavi v tenorju šele neposredno nato izza osminske pavze, toda tokrat $\mathrm{v}$ dvakrat diminuiranih notnih vrednostih (namesto polovinke osminke).

Uporabo treh povsem različnih tem hkrati odkrijemo $v$ kompoziciji št. XXIII, ki je svečan slavospev sv. Trojici. Za mogočnim prvim odsekom, uvedena $\mathrm{z}$ imitacijo med tenorjem in cantusom, katera pa je zaradi njene absorbiranosti $v$ masivno akordsko gmoto glasov skoraj nezaznavna, izstopita najprej kot kontrast dve nežni trio epizodi soprana, quinte in tenorja oziroma tenorja, sexte in basa na besedi 
»Sancta Trinitas", ki temeljita v glavnem na imitaciji iste teme. Neposredno sledi krepak šestglasni odsek, tu pa so $\mathrm{v}$ imitacijski proces vpletene istočasno tri teme. Ni izključeno, da ima tak način oblikovanja simboličen pomen $\mathrm{v}$ smislu poudarjanja nedeljivosti božje troedinosti in ga je torej narekoval tekst (»atque indivisia unitas «), enako kot sta besedi »Sancta Trinitas« morda tudi narekovali število treh glasov v obeh prejšnjih epizodah.

Kot primer umetne kontrapunktske gradnje omenimo posebej še kompozicijo št. V, ki je zasnovana v obliki dvojnega kanona. Gre torej za združitev dveh kanonov, od katerih se odvija prvi med cantusom I in II, a drugi med altom I in II. Oba sta zasnovana $\mathrm{v}$ unisonu, časovni presledek med vox antecedens in vox consequens pa je vsakikrat $v$ trajanju ene brevis. Čeprav predstavlja ta skladba $v$ Lagkhnerjevem opusu po svoji tehnični strani posebnost, moramo ugotoviti, da avtor s takšnim načinom gradnje ni povezal globjo muzikalno izraznost. Po tej strani je skladba dokaj poprečna, razen tega ne moremo spregledati določenih trdot $\mathrm{v}$ izpeljavi glasov.

Nedvomno je eminentna značilnost zbirke »Soboles musica« dvozborje, to pa se kaže $\mathrm{v}$ fiktivni oziroma nakazani in docela realizirani obliki. Gre torej za tehniko, ki jo poznamo kot coro spezzato in pomeni delitev celotnega zbora v dve ali celo več skupin. Svoj najsijajnejši razcvet je doživljala $v$ beneški šoli od znamenitih Willaertovih »Salmi spezzati« (1550) dalje, čeprav so njeni začetki v večglasju dosti starejši in jih posamič lahko zasledujemo $\mathrm{v}$ raznih glasbenih deželah že od druge polovice 15. stoletja naprej. Potem, ko sta to tehniko izpopolnila A. in G. Gabrieli, se je hitro širila. Postala je že kar bolj ali manj splošna evropska kompozicijska pridobitev in sta jo včasih uporabljala npr. tudi Palestrina in Lasso. Razen tega še ne smemo pozabiti dejstva, da je postalo pavziranje nekaterih glasov oziroma izmenjava skupin, potem ko je v drugi polovici 16. stoletja večje število partov $\mathrm{v}$ znatni meri zamenjalo dotlej prevladujoče štiriglasje, že tudi bolj ali manj nujno sredstvo za raznolikost gostote zvočne materije. ${ }^{9}$ Lagkhner je tehniko delitve zbora $\mathrm{v}$ dve skupini rahlo nakazoval mestoma že $\mathrm{v}$ petglasju; bolj ali manj razločno je prisotna $\mathrm{v}$ skoraj vseh njegovih šestglasnih kompozicijah, še posebno evidentna pa je v okviru osemglasja. Največkrat vstopi druga skupina na zadnjem akordu prve, včasih tudi neposredno izza njega ali pred njim. Pri tem le redka ponovi glasbeno frazo prve, navadno prinaša novo gradivo, čeprav se besedilo pogosto ponovi.

Od šestglasnih kompozicij je grajena dosledno v načinu dvozborja št. XVII, kjer je zbor deljen v višjo (cantus, sexta, alt) in nižjo skupino (tenor, quinta, bas), ki se večinoma med seboj izmenjujeta. Vodi višja, nastopi nižje zbujajo vtis odgovora oziroma odmeva, na posameznih mestih pa se obe združita v sonorno tonsko maso. Takšno trganje zvoč-

${ }^{9}$ Jeppesen K., ib., 172-173. 
ne gmote seveda ne dopušča širšega razpleta melodičnih linij. Zato izrazito dominira homofonija in tudi kolikor še lahko govorimo o polifoniji, je čisto preprosta oziroma jo občutimo bolj kot »polifonsko poživljeno« homofonijo. Z izjemo dveh odsekov (»Postquam consumati sunt dies octa in »quod vocatum erat ab Angeli«), kjer višjo skupino doslovno ponovi nižja, prinaša le-ta kot nadaljevanje ali dopolnilo novo muzikalno materijo. V skladbi, katere melodika in harmonija sta preprosti, učinkuje predvsem omenjeno izmenjavanje in povezovanje skupin kakor tudi vseskozi pregledna členjenost celote. Besedilo, kratko poročilo o Kristusovem obrezovanju in poimenovanju ne nakazuje možnosti intenzivnejšega doživljanja vsebinskega ozadja in tudi ne daje povoda za muzikalno slikanje. Zato je ton kompozicije objektivno distanciran in pripoveden, pri tem pa je očitna težnja za jasno in pravilno deklamacijo.

Tehnika dvozborja je precej izrazita tudi $\mathrm{v}$ kompoziciji št. XXI, ki zveni kot vzvišena, $v$ nadzemeljsko zazrta meditacija, kar ustreza besedilu, čigar tema je mistična moč obhajila. Kompozicija se večinoma odvija kot umirjeno izmenjavanje dveh skupin. Tokrat vodi spodnja in ji zgornja sledi, ob posameznih nastopih pa prinašata dosledno novo gradivo. Po strukturi je njun stavek precej raznolik in sega od stroge oziroma svobodne imitacije prek prostega kontrapunkta in psevdopolifonije do enostavne homofonije. Čeprav radostni del na besedo "Alleluia« v tridelni menzuri, ki se loči od sicer kontemplativnega tona kompozicije, združuje pravzaprav vseh šest glasov, je tudi tu občutna delitev $\mathrm{v}$ dve skupini, ki se med seboj ritmično in motivično stalno dopolnjujeta (Pr. 9).

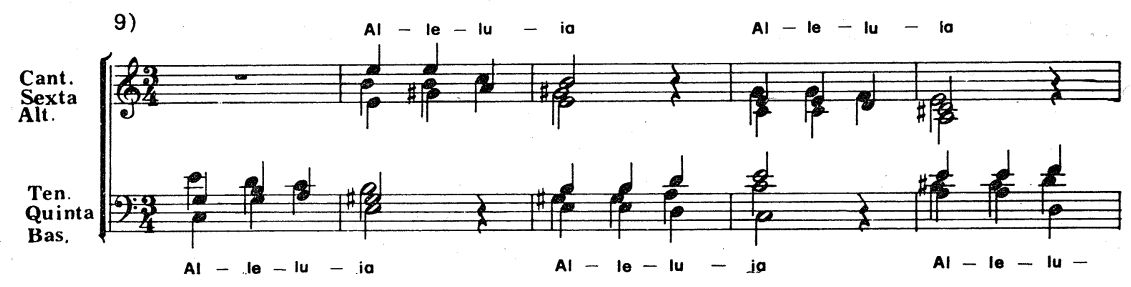

Primer imitacijske povezanosti obeh sicer strogo homofonih skupin je osrednji del kompozicije št. XVIII v tridelni menzuri. Najprej izvede zgornja melodično preprost sedemtaktni stavek, ki avtentično kadencira na toniki. Čim se ta konča, prineseta njegova začetna takta neposredno drug za drugim spodnja in spet zgornja skupina glasov. Takoj sledi oktavo niže še ponovitev celotnega stavka, ki jo cantus, sexta in alt harmonsko dopolnjujejo.

Za tehniko delitve zbora je zlasti $\mathrm{v}$ kompoziciji št. XIX značilno večkrat hitro izmenjavanje višje in nižje skupine. Ta način je $\mathrm{v}$ beneški šoli razvil predvsem Andrea Gabrieli, medtem ko sta si zbora pri 
Willaertu še navadno sledila $\mathrm{z}$ daljšimi odseki. $\mathrm{V}$ omenjeni kompoziciji je najbolj razviden $\mathrm{v}$ zadnjem delu, ki impresionira tudi s svojim zvočno stopnjevanim in mogočnim zaključkom. Gre za stalno, a ne utrujajoče ponavljanje ene same triglasno harmonizirane misli (a) in akordskega bloka (b), sestoječega iz T, D in T, ki si ju obe skupini, deloma ob harmonski dopolnitvi, med seboj podajata ( $P r .10)$. Ceprav

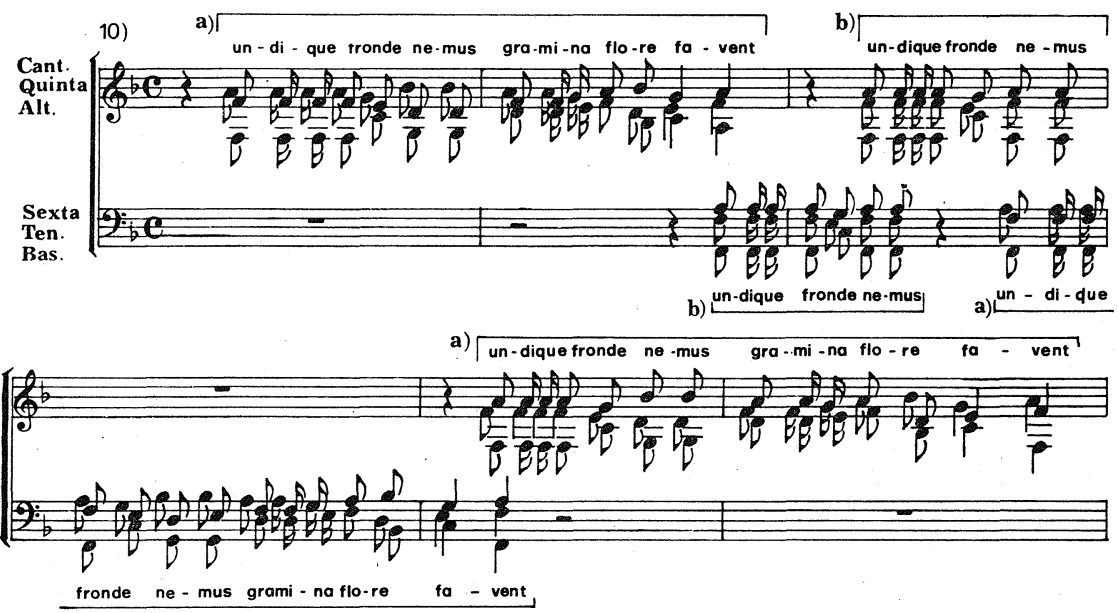

je težišče povsem na sonornosti in stavek po svoji preprosti akordski strukturi in enolični, skoraj psalmodično recitativni melodiki, spominja na falso bordone ki so ga $v$ Italiji radi gojili $v 16$. in še zgodnjem 17. stoletju, je prav $s$ takšnim načinom dosežena znatna razgibanost celote. Sicer pa kaže ta kompozicija, v kateri dominira v skladu s himničnim besedilom o Kristusovi zmagi nad peklom, svečan ton, nasploh smotrno uravnavanje gostote zvočnega tkiva od dveh ali treh pa do občasnega vključevanja vseh šest glasov $v$ glasbeno dogajanje. Nič manj smotrno ni izkoriščanje posameznih glasovnih leg - visoke, nizke, srednje - ter njihovo medsebojno kontrastiranje in združevanje. Kot je evidentna težnja za čisto zvočnim efektom, ki na nekaj mestih že povsem prevlada, pa je še $v$ znatni meri prisotna tudi skrb za uravnovešeno izpeljavo glasovnega tkiva. Tako nas $\mathrm{s}$ svojo igro spevnih melodičnih linij, ki so vezane na imitacijsko obravnavano osnovno temo, privlači že uvodni del. Še bolj pa je izrazit razplet v načinu svobodne imitacije vstopajočih glasov $v$ kratkem odseku »et astra tenet«.

$\mathrm{V}$ sedemglasni kompoziciji št. XXV, ki temelji na tekstu binkoštne antifone in se začenja imitativno štiriglasno, je mogoče razumeti združen nastop celotnega zbora simbolično, da se ponazori smisel besed »... eran omnes pariter in eodem loco...», torej skupnost vseh na 
istem kraju. Poseben poudarek je dal skladatelj bistvenemu pomenu binkoštnega dogodka, tj. razsvetljenju po sv. Duhu. Zato je stavek »Tanquam spiritus vehementis, et replenit totam domum " komponiral dvakrat zapored: prvič za nižjo in drugič za višjo zborovsko skupino, nakar je ob ponovitvi besedi »et replanit totam domum « še obe spojil v krajšem imitativnem pasusu.

Od osemglasnih skladb imata št. XXVI in XXVIII izrecno oznako Chorus I in Chorus II, ki sta enake višine in ju sestavljajo cantus, alt, tenor in bas. Št. XXVI temelji na istem tekstu kot petglasna št. VIII, tj. na angelovem oznanilu pastirjem o Kristusovem rojstvu, vendar je tokrat uglasibitev daljša in sijajnejša, kar je razumljivo spričo dosledne uporabe tehnike cori spezzati, ki z izmenjavanjem in združevanjem dveh zborov, zdaj $\mathrm{v}$ daljših, a zdaj $\mathrm{v}$ čisto kratkih odsekih po le nekaj taktov, narekuje tudi več ponavljanja besedi. $V$ enem kot drugem primeru dominira svetlo in veselo razpoloženje. Čeprav je št. XXVI $\mathrm{v}$ eolskem načinu, se relativno pogosto pojavljajo durovi trizvoki, ki so večkrat rezultat kromatskega zvišanja terce. Tako se skladba že začenja na besedo »Angelus« $z$ velikim toničnim trizvokom prvega zbora, ki ga takoj prevzame $\mathrm{v}$ spremenjeni legi drugi zbor in $\mathrm{mu}$ doda še durovo subdominanto. Neposredno nadaljevanje napovedanega stavka je komponirano kot imitacija $v$ unisonu med prvim in drugim zborom, nakar sledi njun skupen nastop in zaključek uvodnega dela $z$ emfatično fermato note brevis, ki ima tu pravzaprav pomen figure aposiopesis. Začetek angelovega direktnega govora podčrtujejo pregnantna motivika, dosledna homofonija in homoritmičnost, hitra izmenjava zborov in razločen odklon od osnovnega modalnega okvira. Najvažnejši del sporočila »quia natus est vobis hodie Salvator mundi« je oblikovan kot imitacija med obema zboroma, ki pa je tokrat $v$ intervalu zgornje terce. Pri tem sta tema in njena imitacija med seboj diferencirani tudi glede tonalitete, tako da nastopi prva $\mathrm{v}$ osnovnem tj. eolskem, a druga $v$ jonskem načinu. Poslanica izzveni $z$ odklonom $\mathrm{v}$ dorsko tonaliteto in kratko frazo $\mathrm{v}$ enostavni štiriglasni harmonizaciji, ki ju zbora na besedi »Salvator mundi« izmenjaje ponavljata. Zadnji del kompozicije je preprosto silabični jubilus (Alleluia) $\mathrm{v}$ konstantno krepkem ritmu in odet $\mathrm{v}$ masivno akordiko. Dasiravno ne manjka vesele razigranosti, je daleč od zanesene radosti.

Kompozicija št. XXVIII, ki je slovesna in umirjena hvalnica sv. Trojici, nas privlači predvsem s svojo mehko in masivno ter tu in tam svojstveno obarvano zvočnostjo. Kar se da močno nasprotje $\mathrm{k}$ dosledni ploskovitosti predstavlja zanosni sklepni »Amen« za oba združena zbora, ki zasluži pozornost zaradi polnosti in intenzitete polifonega življenja. Zgrajen je imitacijsko iz treh tem na trdni harmonski osnovi basa $\mathrm{s}$ pedalnimi toni, ki predstavljajo funkcije T, D, S in Tp.

Ceprav ni zabeležena $\mathrm{z}$ oznako Chorus I in Chorus II, je izrazit primer tehnike cori spezzati tudi osemglasna kompozicija št. XXVII. Potem, ko je na začetku eksponirana značilna pettonska tema, ki se 
postopoma spušča in $\mathrm{v}$ imitaciji prepaja celotno glasovno tkivo, poteka kompozicija v rednem izmenjavanju višje (cantus superius, cantus inferius, altus superius, altus inferius) in nižje skupine (tenor superius, tenor inferius, bassus superius, bassus inferius). Do združitve obeh pride izjemoma le tam, kjer je hotel skladatelj efekt mogočne sonornosti. Kljub delitvi zvočne gmote pa ima tu pri gradnji polifonija važno vlogo, saj je večina odstavkov zasnovana imitacijsko. Včasih temelji nastop ene in druge skupine kar na isti tematiki, sredstvo za kontrast pa je pri tem seveda glasovna lega - svetlejša visoka in temnejša nizka. Medtem ko imitacijsko izpeljani vzklik »Alleluia « v tridobni menzuri, ki ga intonirajo nižji glasovi, višji enostavno ponove, pride sicer do določenega preoblikovanja osnovnega tematskega gradiva.

Čeprav prevladuje $\mathrm{v}$ melodiji postopno melodično gibanje, kar velja zlasti za tonska zaporedja $\mathrm{v}$ kratkih notnih vrednostih (fuse, semiminime), ne manjka skokov, ki jih je zdaj več zdaj manj. Kot mnogi njegovi sodobniki, a za razliko od Palestrine, uporablja Lagkhner po dva ali celo tri skoke zapored $\mathrm{v}$ isto smer tudi $\mathrm{v}$ vrednosti semiminim. Ne glede na to se zdi kombinacija kvinte in velike terce $\mathrm{v}$ hitrem postopku navzdol $\mathrm{v}$ kompozicijah št. $\mathrm{V}$ in $\mathrm{XV}$ nenavadna (Pr. $11 \mathrm{a}$ in b), saj za takšno zvezo pripominja Andrews, da je v Byrdovem opusu sploh ne srečamo. ${ }^{10} \mathrm{Z}$ vidika strogega stavka pa učinkuje $\mathrm{v}$ št. V neuglajeno skok oktave navzgor, ki mu ne sledi neposredno gibanje $\mathrm{v}$ nasprotni smeri, ampak še korak navzgor ${ }^{11}$ (Pr. 12).

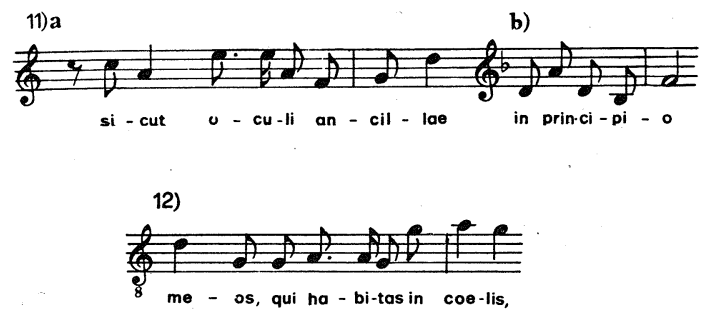

Za melodiko zbirke »Soboles musica « je po eni strani karakteristična kar izdatna melizmatika, po drugi pa nič manj preprosta silabičnost. Ta se rada veže na kratke notne vrednosti in tonsko ponavljanje. Tako imajo melodije večkrat izrazito deklamativen oziroma parlandiran značaj ter se s svojo priostreno ritmiko tesno prilegajo besedilu oziroma iz njega izhajajo. Ustrezno temu se gibljeta tudi tvorba motivov in tematika pretežno $\mathrm{v}$ krogu majhnih intervalov in se izogibata večjim ekspresivno poudarjenim intervalom, kot sta kvinta,

10 Andrews H. K., ib., 65. 1958, 80 .

11 Morris R. O., Contrapuntal Technique of the $16^{\text {ht }}$ Century, Oxford 
ali seksta. V cantusu kompozicije št. XXVII pa preide melodija v zvezi S ponavljajočimi se besedami »et ego eum tollam« celo v golo recitacijo na enem samem tonu. Da zbuja parlandirana melodika s svojim gibanjem okrog istih tonov včasih vtis enoličnosti, ni mogoče zanikati. Seveda pa je tedaj navadno težišče na zvočnem, akordnem učinku, ki lahko to negativnost odtehta (Pr. $13 \mathrm{a}$ in b).
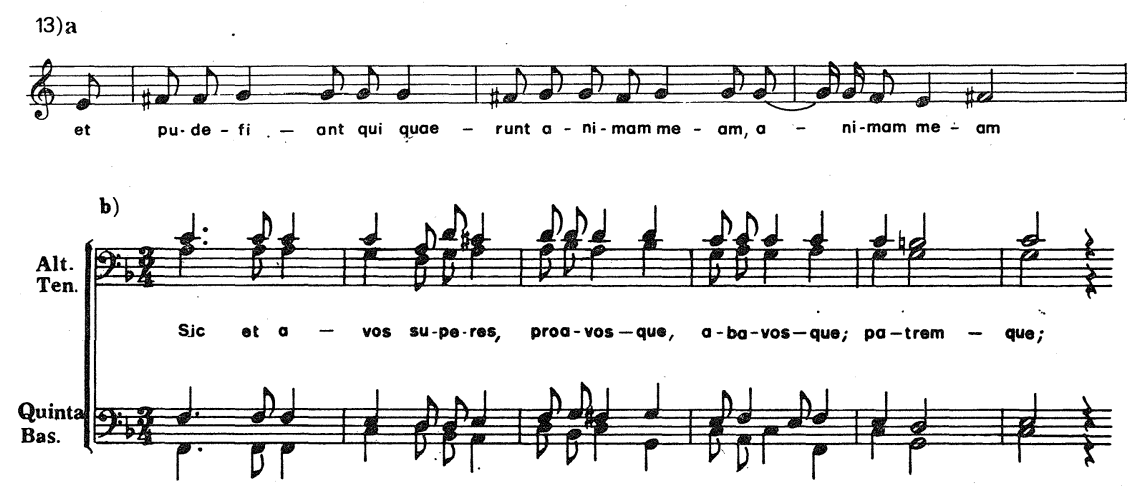

Povsem drugačna je melodika kantabilnega značaja, ki je bolj ali manj odeta $v$ krajše in daljše melizme in kaže ponekod prav lepo uravnovešeno lokovno strukturo (Pr. 14). Kljub temu, da je sam obseg glasov v okviru celotnih kompozicij dokaj velik - navadno decima ali tudi več - pa se odvijajo posamezne fraze oziroma odseki melodij le redko $\mathrm{v}$ razponu, ki presega oktavo.

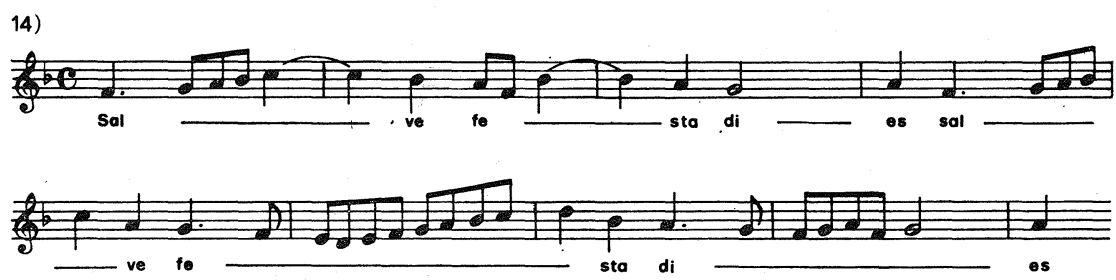

Podobno kot $\mathrm{v}$ obeh poznejših Lagkhnerjevih zbirkah je melizmatika pretežno abstraktno muzikalne narave. Seveda pa ni mogoče $v$ vrsti primerov zanikati, da služijo melizmi za ponazarjanje podob $\mathrm{v}$ tekstu, izražanje radostnega afekta in poudarjanje vsebinsko važnih besedi. Gre pravzapav za posebno figuro, ki so jo teoretiki vse od J. Burmeistra, tj. od začetka 17. stoletja dalje, označevali zelo splošno kot hypotyposis. ${ }^{12}$ Prav učinkovito je npr. Lagkhner ilustriral pojem hitenja in gibanja v zvezi z besedami "festina " (= hiti), "avertantur" (= naj se poženejo v beg) in sintres« (= greš) v kompozicijah št. IX in 
III, kjer je uporabil $\mathrm{v}$ enem ali kar več glasovih hkrati hitro tekoče pasaže. Izrazito ilustrativnega značaja je tudi melizmatika, ki zajema na besedo "sonus" (= glas, zvok) z izjemo basa kot harmonskega fundamenta vse parte kompozicije št. XXV.

Čravno muzikalno slikanje oziroma ekspresivno poudarjanje teksta, ki je bilo $\mathrm{v}$ tistem času zlasti močno razvito $\mathrm{v}$ madrigalu, a je že tudi zajelo sakralno glasbo, ni eminentna poteza Lagkhnerjevega opusa, zasluži posebno pozornost $\mathrm{v}$ kompoziciji št. XIV posrečena uporaba dvigajoče se melodike, ki ponazarja gibanje navzgor oziroma konkretno Kristusov vnebohod. Ta tip melodike je kot figuro anabasis pojmovno zajel leta 1650 A. Kircher. ${ }^{13} \mathrm{~V}$ omenjeni skladbi veže Lagkhner besedi »Ascendit Deus« V ne prepreprosto, a dovolj značilno temo petih tonov $\mathrm{v}$ postopu navzgor. To temo intonira najprej quinta, medtem ko izvaja cantus florirano glasbeno misel. V presledku ene dobe in pol nastopi imitacija teme, ki je še razširjena za dva tona navzgor, na spodnji kvarti in oktavi istočasno $\mathrm{v}$ altu in tenorju (Pr. 15). V neposrednem nadaljevanju se vsi štirje zgornji glasovi ob besedah »in iubilo« (= v radosti) razpojejo v vsebinsko pomembnih melizmih. Ko se psalmov polverz (»Ascendit Deus in iubilo«) ponovi, se analogno ponovi glasbena zasnova, le da je tokrat tema $\mathrm{v}$ basu, tenorju in cantusu, za kontrapunkt pa služi kratka in nasprotno usmerjena melizmatska misel, ki jo v imitaciji prineseta quinta in alt. Podobno kot v prvi polovici psalmovega verza je glasba $v$ službi programa $v$ njegovi drugi

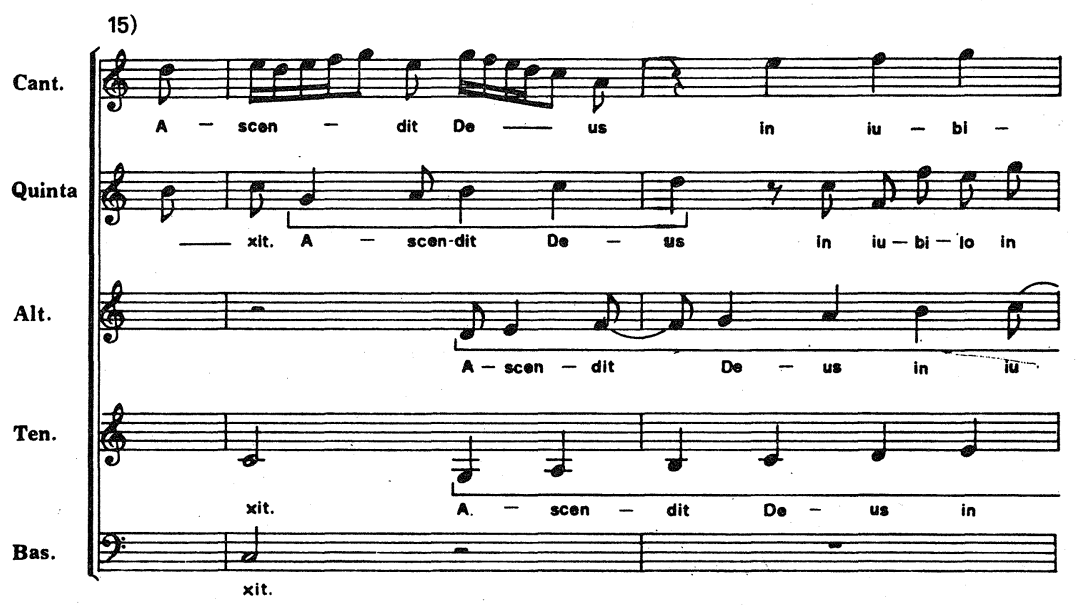

12 Burmeister J., Musica poetica, Rostock 1606, 62 (Faksimilni ponatis, izd. M. Runke, Kassel-Basel 1955); Schmitz A., Die Figurenlehre in den theoretischen Werken J. G. Walthers, Archiv für Musikwissenschaft IX, 1952, 79 ss.; Busch H. J., Moteti Jakoba Gallusa in nauk o figurah $v$ prvi polovici 17. stoletja, Iuzikološki zbornik V, Ljubljana 1969, 40 ss.

13 Kircher A., Musurgia universalis, Rim 1650, 145. 


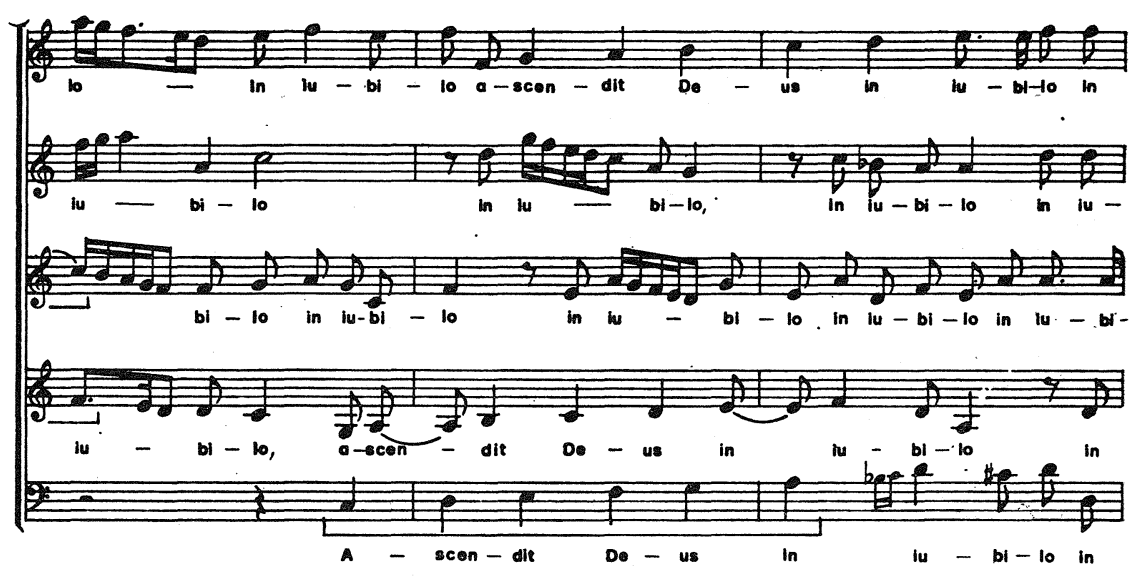

polovici. Tu izstopi jedrnata in markantna tema tenorja in basa na besede »et Dominus in voce tubae« (= in Gospod ob zvoku trobente), ki $\mathrm{s}$ tonskim ponavljanjem in dvema kvartnima postopoma navzgor živo zbuja predstavo klica trobente (Pr. 16). ${ }^{14}$

16)

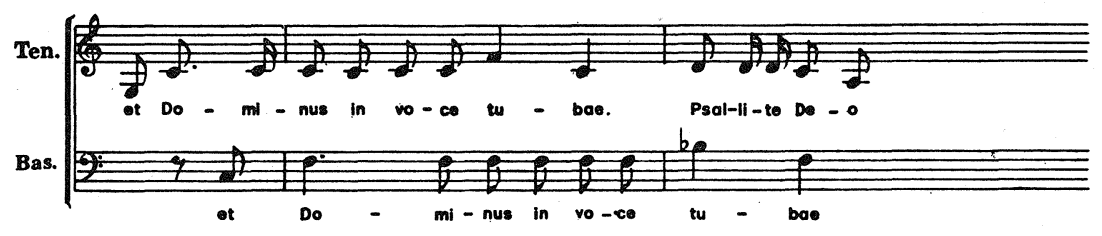

Izvrstne primere podčrtavanja besedila s pomočjo melodike vsebuje tudi kompozicija št. XX. Če je v prejšnji skladbi Kristusov vnebohod omenjen le na enem mestu, je zdaj glavna tema in tako preveva celotno kompozicijo radostno razpoloženje, ki izhaja tudi iz svetle miksolidijske tonalitete. $\mathrm{Tu}$ je Lagkhner najprej plastično nakazal razsežnost nebesnega svoda s polagoma se vzpenjajočo melodično linijo nekaterih glasov (bas in tenor »intuentes in coelum? «, cantus »in coelum «) (Pr. $17 \mathrm{a}$ in b). Nastopa figura circulatio, krožno melodično gibanje, ki jo je enako kot usmerjeno melodično tvorbo (anabasis, katabasis), opisal šele Kircher. Nanjo naletimo pogosto v kompozicijah 16. stoletja, med drugim tudi pri Gallusu, ki jo je uporabil na isto besedo V LIX motetu IV. zvezka zbirke »Opus musicum «.15 V nadaljevanju Lagkhnerjeve kompozicije izstopita iz ritmično razgibanejšega toka emfatični besedi »Hic Jesus« (= to oziroma tu Jezus) kot masiven

14 Kircher A., ib., 145.

15 Busch H. J., ib., 50 . 


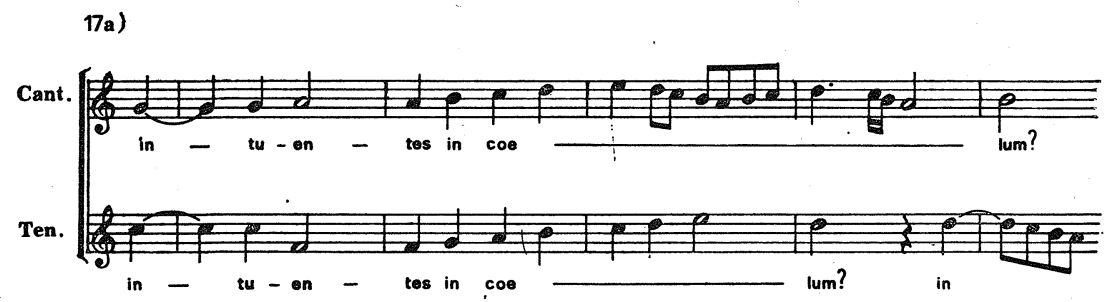

b)

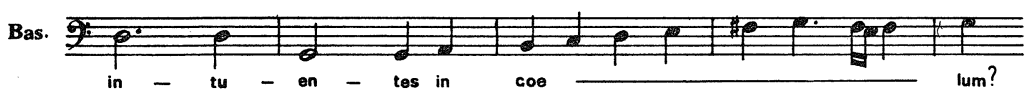

blok zadržanih akordov $\mathrm{v}$ dolgih vrednostih (semibrevis, brevis), kar ustreza figuri, imenovani noema. Neposredno zatem je vnebohod lepo ponazorjen s postopnim dviganjem treh spodnjih glasov na tekst »qui assumptus est a vobis « (= ki je bil vzet od vas v nebesa), torej s figuro anabasis (Pr. 18), kateri sledi na »coelum« spet circulatio. Zlasti živo je upodobljen vnebohod ob besedi »euntem《 (= idoč v nebo), kjer je predstava gibanja intenzivirana tako, da vstopa vseh šest glasov z rastočo melodično linijo zaporedoma $\mathrm{v}$ načinu svobodne imitacije, medtem ko so same linije izrazito melizmatske.

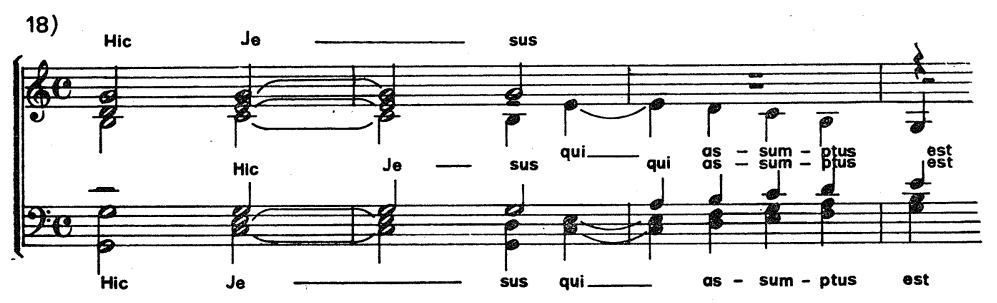

Oblikovno se »Soboles musica« znatno loči od zbirk »Flores Jessaei in "Florum Jessaeorum«. Slednji vsebujeta skladbice, zasnovane po isti dvo- ali tridelni shemi s stalnim ponavljanjem posameznih delov, prva pa kompozicije širših dimenzij, ki ne slede določenemu oblikovnemu modelu. Zanje je značilna svobodna prekomponirana forma. Sestoji se iz večjega ali manjšega števila različno dolgih odsekov, ki se razlikujejo po tematiki in strukturi. Vsak od njih obdeluje običajno po eno krajšo miselno enoto besedila in se zaključuje $s$ kadenco. Meje med njimi pa seveda niso viselej ostro zaznavne, ker glasovi ne kadencirajo istočasno in tako lahko posamezni odseki skoro neopazno prehajajo drug $\mathrm{v}$ drugega. Takšne skladbe so torej, kolikor so vezane na nabožna besedila; tipični moteti. Vendar se od njih ne razlikujeta obe 
posvetni pesmi niti glede oblikovne zasnove niti načina gradnje in izraznosti. Čeprav gre na splošno za nizanje in spajanje odsekov, je $\mathrm{v}$ nekaterih primerih mogoče govoriti o zasnovi $\mathrm{v}$ dveh ali treh večjih delih. Pri kompozicijah št. XVII, XIX, XXII in XXVIII se v širšem smislu kaže oblika $A B$, pri št. XVIII pa $A B C$. Tako je npr. prvi del kompozicije št. XVII umirjenejši, drugi pa bolj razgiban; v njem prevladujejo kratke notne vrednosti in deklamativnost, razen tega je še značilna strogo proporcionirana gradnja iz stavkov enake dolžine. V kompoziciji št. XVIII je prvi del imitativen in nekoliko bolj zadržan, srednji homofon in $\mathrm{v}$ tridelni menzuri, zadnji pa vodi zanosno $\mathrm{k}$ zaključku. Kompozicije št. III, XI in XV nakazujejo dvodelno, št. VII pa tridelno formo s ponovitvijo drugega oziroma tretjega dela, ki pa je izpisana, ker sta med seboj zamenjana zgornja glasova $\left(\mathrm{ABB}_{1}\right.$ oziroma $\mathrm{ABCC}_{1}$ ). Sicer zasledimo ponovitev krajšega pasusa, in to prav tako z zamenjavo obeh zgornjih partov, pri kompozicijah št. X, XIV, XXI in XXVII.

V zvezi s ponavljanjem je tudi refren kot občasno nastopajoč glasbeni člen, ki prispeva $\mathrm{k}$ trdni povezanosti delov $\mathrm{v}$ zaokroženo celoto. Ta način gradnje je imel važno vlogo $v$ zgodnjebaročnem cerkvenem koncertu in ga je že znal imenitno uporabiti npr. G. Gabrieli na besedo »Alleluia « v svojem znamenitem motetu »In ecclusiis«. Lagkhner se ga poslužuje $\mathrm{v}$ kompozicijah št. XX in XXV, kjer se enako veže na besedo »Alleluia in je izraz radostnega efekta. Kot pri Gabrieliju je $\mathrm{v}$ poskočnem tridobnem metrumu, preprosto homofon in homoritmičen. $\mathrm{V}$ kompoziciji št. XX izstopa tudi po svoji harmonski strukturi. Obakrat je na koncu kompozicije še razširjen in vodi do radostno stopnjevanega zaključka.

Ko poskušamo zbirko »Soboles musica D. Lagkhnerja in njegovo doslej znano ustvarjalnost stilno opredeliti, ne bo odveč, če si na kratko prikličemo v spomin tedanjo glasbeno situacijo v Evropi. Najprej nikakor ne smemo pozabiti, da so bili večji del renesanse dominantni Nizozemci, ki so že konec 15. in na začetku 16. stoletja razvili sijajno polifono tehniko. Ta je dosegla ob upoštevanju italijanskega avtohtonega elementa končno in idealno dovršenost $\mathrm{v}$ rimski šoli, ostala pa je ne glede na individualno disponiranost in orientacijo važna osnova še tudi za vse poznorenesančno glasbeno snovanje, da o njeni eminentnosti $\mathrm{v}$ območju stila obligato naslednje baročne epohe sploh ne govorimo. Ko so v drugi polovici 16. stoletja v Italiji že vedno bolj stopali $\mathrm{v}$ ospredje domači skladatelji, je potekalo glasbeno delo $\mathrm{v}$ nemških deželah še nekaj časa $v$ znamenju hegemonije Nizozemcev. Zlasti je bil močan Lassov vpliv, ki je ponekod občuten tudi pri Nemcih Lechnerju in Eccardu. Novejša glasbena stremljenja, ki postopoma zaključujejo renesanso in deloma že uvajajo barok, je v Italiji odločno uresničevala z zvočno masivnostjo, koloritom in večzborjem beneška šola. Ta prizadevanja so se vidno uveljavila pod konec 16 . in na začetku 
17. stoletja že tudi onkraj Alp, za kar gre predvsem zasluga mojstrom kot so Gallus, Hassler, H. in M. Praetorius ali Gumpelzhaimer. ${ }^{16}$

$\mathrm{Na}$ prostoru nekdanje avstrijske države so imeli Nizozemci najmočnejšo pozicijo $\mathrm{v}$ cesarski dvorni kapeli v Pragi, ki jo je do svoje smrti 1603 vodil sam Ph. de Monte. Čeprav je bil cesarski dvor dokaj rezerviran nasproti novejši italijanski glasbi, izkazuje njegov doslej še ne dovolj raziskani glasbeni inventar že od konca 16. stoletja dalje tudi italijansko dvozborno literaturo. Kot na cesarskem dvoru so Nizozemci vsaj sprva $\mathrm{v}$ drugi polovici stoletja dominirali tudi $\mathrm{v}$ nadvojvodskih rezidencah $v$ Innsbrucku in Gradcu. Vendar je prav Gradec postal relativno kmalu važno sprejemališče novejših italijanskih vplivov, saj je tu v letih 1570-1575 deloval kot dvorni kapelnik znani Benečan Hannibale Padovano, ki mu je sledila vrsta italijanskih glasbenikov, med katerimi so $\mathrm{v}$ prvih letih 17. stoletja ustvarjalno izrazitejši P. A. Bianco, F. Stivori in R. Ballestra. ${ }^{17}$ Postopoma so prodirali Italijani od konca stoletja dalje še $\mathrm{v}$ drugih pomembnih glasbenih središčih, predvsem v Salzburgu in Innsbrucku, ob njih pa so se začeli nekje po letu 1600 uveljavljati deloma pod italijanskim vplivom tudi domači skladatelji kot G. Poss, S. Erthel, Chr. Strauss, P. Gutfreund (Bonamico) in končno A. Stadlmayr. Kolikor je mogoče razbrati iz dosedanjih raziskovanj in izdaj kompozicij, spada produkcija teh skladateljev pretežno že $\mathrm{v}$ čas po letu 1610. Podobno kot produkcija njihovih italijanskih kolegov pa omahuje stilno tudi ta med preteklostjo in novejšo zvočnostjo. Takšna, včasih še precej konservativna orientacija, je na področju cerkvene glasbe okrog leta 1600 oziroma neposredno zatem splošen pojav tako na katoliški kot protestantski strani, le da se je slednja $\mathrm{v}$ avstrijskih deželah, kjer se je čutila ideološko ogrožena, pokazala bolj zadržano glede sprejemanja stilnih vplivov katoliške Italije. ${ }^{18}$

Sicer pa ne smemo pozabiti, da je bila tudi cerkvena glasbena ustvarjalnost najbolj avantgardnih mojstrov kot celo G. Gabrielija ali Monteverdija stilno dvolična, tudi ta dva sta pisala poleg skladb, ki razodevajo ves zvočni sijaj, še takšne, ki kažejo, izrazito naslonitev na starejšo tehniko. ${ }^{19}$ Afektivno poudarjeni zgodnjebaročni stil z bassom continuo je odjeknil $\mathrm{v}$ sakralni glasbi močneje šele leta $1610 \mathrm{z}$

16 The New Oxford History of Music IV, London 1968, 276 ss.; Reese G., Music in the Reinaissance, New York 1959, 679.

17 Flotzinger R.-Gruber G., ib., 241 ss.; 251, 256 ss., 261, 292 ss.; Suppan W., ib., 192.

18 Flotzinger R.-Gruber G., ib., 286, 300-301.

19 Das Chorwerk 67, Kassel 1957, Engelbrecht Chr. Einleitung; prim. tudi kompozicije G. Gabrielija, objavljene v tem zvezku kot eminenten primer stila, ki se povezuje $\mathrm{s}$ tradicijo Palestrine in Lassa. Izrazito polifono orientacijo kažejo npr. moteti beneškega s'kladatelja C. Merula, objavljeni v zbirki Sacred music III, Corpus mensurabilis musicae 51 ali Missa prima sexti toni G. Croceja v zbirki Monumenta Veneta excerpta I, Bologna 1963. 
Monteverdijem in A. Grandijem ter kmalu nato na severu s Schützom in J. H. Scheinom.

$\mathrm{S}$ prikazano glasbeno situacijo $\mathrm{v}$ Evropi in še posebej $\mathrm{v}$ Nemčiji in Avstriji se tudi ujema stilna podoba zbirke »Soboles musica«, za katero je ravno značilna omenjena dvojnost. Izdatna uporaba polifonije in imitacije še kaže njeno precejšnjo navezanost na starejšo tradicijo visoke renesanse. To $\mathrm{v}$ prvi vrsti povezujemo $\mathrm{z}$ nizozemskimi mojstri, katerih glasbena govorica je bila že od začetka 16 . stoletja naprej neglede na uveljavljanje specifičnih "nacionalnih " posvetnih oblik pravzaprav internacionalni glasbeni jezik Evrope. Istočasno v obravnavani zbirki seveda nikakor ne moremo prezreti že kar močnega vpliva novejših poznorenesančnih in deloma zgodnjebaročnih stilnih tokov, katerih prvotni vir je Italija in zlasti beneška šola. Tu mislimo pri Lagkhnerju predvsem na nakazano ali realno dvozborje, pomemben porast homofonije in široko uporabo navidezne polifonije kakor tudi ritmično razgibanost in kontrastnost. Medtem ko se odraža omenjeni vpliv le rahlo $v$ mestoma nekoliko barvitejši harmoniji, ki se včasih tudi razločno nagiblje $v$ novo tonalnost, pa sodobnejših prizadevanj za ekspresivno podčrtovanje besedila $z$ disonanco in z zvečanimi in zmanjšanimi melodičnimi postopi, ki so bila $\mathrm{v}$ drugi polovici 16. stoletja posebno močna $v$ madrigalu, a so občasno dovolj razločna tudi pri nekaterih velikih mojstrih poznorenesančne sakralne glasbe, $v$ »Soboles musica« sploh ni zaslediti. Kolikor že tu in tam odkrijemo svobodnejše tretiranje disonance, se zdi, da ga nikjer ni mogoče pripisovati posebnim ekspresivnim intencijam.

V zvezi z beneškimi stilnimi potezami pri Lagkhnerju nas zanima še vprašanje, kje in kako se je skladatelj seznanil s kompozicijsko tehniko te šole. Morda že v mladosti v bližnjem Gradcu. Vendar je to le ugibanje, ki ostane brez stvarne podlage, vse dokler ne bi uspelo posvetiti kaj več $\mathrm{v}$ temo skrivnosti, v katero je zavita njegova življenjska pot. Razen tega je bila, kot sem že poudaril, tehnika večzborja v tistem času že bolj ali manj splošna glasbena pridobitev, s katero je bilo mogoče priti v stik na najrazličnejše načine po številnih tiskih in rokopisih kompozicij beneških in drugih skladateljev. Vsekakor ostane za našo oceno važno dejstvo, da odsevajo beneške značilnosti, čeprav seveda ne $\mathrm{v}$ tisti sijajni in monumentalni podobi, kot sta jo razvila A. in G. Gabrieli, le dovolj razločno v Lagkhnerjevi ustvarjalnosti. To pa jasno kaže, da se Lagkhner ni zapiral pred glasbenim razvojem v svetu. Bil je s sodobno kompozicijsko tehniko kar na tekočem in tako tudi ni bistveno zaostajal za vrsto skladateljev, ki so ustvarjali $\mathrm{v}$ Avstriji konec 16. in prva leta 17. stoletja.

Kolikor doslej poznamo ustvarjalnost Daniela Lagkhnerja, lahko nedvomno sodimo, da predstavlja večje število kompozicij zbirke »Soboles musica umetniško najvrednejši in tudi stilno najnaprednejši del njegovega opusa. Tu njegova ustvarjalna fantazija ni bila tako vezana na omejena izvajalna sredstva kot $\mathrm{v}$ obeh nekoliko mlajših zbirkah in 
se je lahko močneje sprostila v okviru širših dimenzij. Zato le »Soboles musica « razodeva $\mathrm{v}$ dokaj jasni luči Lagkhnerjeve ustvarjalne sposobnosti ob vstopu $\mathrm{v}$ novo stoletje. Ta zbirka pa tudi še določneje kot poznejši zbirki izpričuje, da je bil Lagkhner stilno naprednejši in tehnično dospelejši kot njegov $v$ letih 1588 do 1591 na protestantski stanovski šoli v Ljubljani delujoči nemški sodobnik Wolfgang Striccius, čigar kompozicijski stavek je, kolikor smo ga doslej mogli spoznati, manj akordsko nasičen in blagozvočen. ${ }^{20}$ Če nam odkriva Stricciusova glasbena zapuščina z morebitno izjemo moteta "Exulta satis filia Sion« avtorja $\mathrm{v}$ zgodnjem ustvarjalnem obdobju, ${ }^{21}$ nam kažejo ohranjena dela D. Lagkhnerja kot že kar zrelega skladatelja. V enem kot drugem primeru pa ni mogoče podati zanesljive in zaokrožene stilne podobe skladatelja na podlagi kompozicij, ki so se nam ohranile oziroma jih do danes poznamo, saj so te po vsej priliki le del njunega življenjskega opusa. Nedvomno še težjo oviro kot nepopolnost ohranjenega opusa predstavlja za njun prikaz dejstvo, da deli ohranjene zbirke kratek časovni presledek. Medtem, ko predstavlja pri Stricciusu mlajša zbirka (»Der Erste Theil Newer Teutscher Gesänge zu Fünff und Vier Stimmen « iz leta 1593) vseeno določen ustvarjalni vzpon in stilni razvoj avtorja, tega za Lagkhnerjevi kasnejši zbirki nikakor ne bi mogli trditi Za razliko od tujca Stricciusa, čigar ohranjene kompozicije nam pomagajo dopolniti podobo glasbenega repertoarja na Slovenskem $\mathrm{v}$ obdobju reformacije, seveda Lagkhner s svojo orientacijo zaradi oddaljenosti kraja svojega delovanja na glasbeno situacijo in razvoj na Slovenskem neposredno ni mogel vplivati. Ne glede na to pa so njegove kompozicije za nas zanimive ne le kot historičen dokument, ampak tudi kot stvaritve umetniške vrednosti glasbenika, ki je izšel iz našega etničnega ozemlja. Marsikatere od njih lahko tudi prispevajo $\mathrm{k}$ sodobnem repertoarju izvajalne prakse stare polifone umetnosti.

20 Sivec J., Kompozicijski stavek Wolfganga Stricciusa; Ljubljana 1972, $33-36,69-80$.

21 Sivec J., ib., 65-68.

\section{SUIMIMARY}

The collection "Soboles musica, id est Cantiones sacrae, quatuor, quinque, sex, septem et octo vocibus, festis anni solmnioribus pie accomodatae" of Daniel Lagkhner (Lackner) was printed in 1602 by Abraham Wagenmann in Nuremberg, whereafter also all the other collections of the same author were published. Two copies have survived, one is kept in the Bishop's Central Library in Regensburg, the other in the Municipal Archives of Kamenz (GDR). The collection is dedicated to Baron Georg Christoph von Losenstein, with whom the composer was engaged as "symphonista" or rather "musurgus" at Loosdorf in Lower Austria. It contains 28 Latin choral works. These are all, with two exceptions (No. XVI. is a song written for Dr. Bierdümphel's wedding and No. XXIV is a musical arrangement of the 
introductory dedication), of a liturgical character and are predominantly based on texts of the Old and New Testament. The compositions are written for various vocal casts; however, contrarily to those in the already known, slightly younger collections, they are never intended for high voices only and thus demand a combination of boys' and male voices or rather a mixed chorus.

On the whole, the texture is rather polyphonic, though there is periodically some explicit homophony not confined only to short blocks of chords or passages in triple measure. Throughout the compositions imitation is more or less present and two thirds of the collection begin in an imitafional way. Here and there, two various themes are used at a time, or two variants of the same theme or rather the theme together with its inversion. Whereas the beginning of No. IX reveals three variants of the same theme, in No. XXIII three completely different themes are used.

An eminent characteristic is the chori spezzati technique, either in a fictitious or a completely realized form. The technique of devided choirs can be detected already in five-part compositions. It is present nearly in all six-part compositions, whereas it comes up most strongly in those written for eight parts. The incipits of the second group are usually on the last chord of the first group, though sometimes proceeding or following the latter. The musical phrase of the first group is rarely repeated; usually, new material is presented, though the old text is likely to recur. No. XIX shows swift exchange between higher and lower groups, which is in the Venetian School the manner developed especially by Andrea Gabrieli, whereas with Willaert the choruses followed each other in longer sections.

Among the modes the mixolydian has precedence. It is combined with texts of joyous character and many a time with passionate divine hymns. This mode is followed by the dorian and ionian, each with the same number of examples. Ionian compositions too are based on texts of high spirited moods. The aeolian mode is least frequent. Apart from the main modality some compositions reflect a longer or shorter presence of one, two or even more other modes. With "Soboles musica", this phenomenon, due to a wider concept, seems to be more explicit than with younger collections. Much more obvious is also the trend towards the new tonality, so that passages in major and minor as well as chromatics are found more frequently - and this represents a shifting away from the modal basis and, in a number of examples, modulation in the newer harmonic sense. On the whole, the chromatics are on the increase, although mostly in the form of alterations, typical of modal texture. An exception is compostion No. I, the concluding section of which contains a D sharp.

The compositions are written in a "durch"-composed form, consisting of a greater or smaller number of passages which vary in their thematics, structure and length. Because of religious texts these compositions are typical motets, and also the two other secular songs follow the same compositional treatment. No. XX and XXV make use of a refrain as a formbuilding element, typical of the early baroque church concerto and effectively used since G. Gabrieli.

Stylistically, the collection "Soboles musica", which oscillates between the past and new sound, reflects the current musical situation in Europe and especially that in Germany and Austria. Extensive use of polyphony and imitation reveals its high renaissance traditional orientation. This is the technique of the masters from the Low Countries, the musical language of Europe which was ever since the late 15th century in spite of specific "national" secular forms internationally understood. At the same time, strong late renaissance and partly early baroque influences, which had begun in Italy and especially in the Venetian School, cannot be overlooked. In connection with Lagkhner this means: fictitious or realized chori spezzati 
technique, rise of homophony, wide use of fictitious polyphony as well as agitated rhythmical contrasts. However, contemporary trends towards expressive underlining of texts with dissonaces as well as with augmented and diminished melodic progressions, which were especially promienent in the madrigal of the latter half of the $16^{\text {th }}$ century, and quite evident in some late renaissance religious of the great masters, are not to be detected in "Soboles musica". Sporadic, freer treatment of dissonance, when found cannot be ascribed to any special expressive intentions. Nevertheless, they do reflect Venetian characteristics, although never in the magnificient and monumental way as developed by A. and G. Gabrieli. Which means that Lagkhner was not cut off from contemporary musical developments and basicly did not lag behind numerous composers, active in Austria at the end of the $16^{\text {th }}$ and the beginning of the $17^{\text {th }}$ centuries.

As far as one can judge from the hitherto researched works of Daniel Lagkhner, a greater number of compositions from the "Soboles musica" collection represent the artistically best and stylistically most advanced part of his opus. This time, his creative imagination was not infected by limited means of performance as in the case of two earlier collections. "Soboles musica" reflects thus Lagkhner's full compositional abilities on the verge of a new century. Although the collection in question comes from a mature composer, the compostions that have hitherto come down to us cannot give a fully reliable stylistic picture of Daniel Lagkhner, for in all probability they represent but a part of his compostional output. 